\title{
The Health Risk of Cd Released from Low-Cost Jewelry
}

\author{
Miloslav Pouzar ${ }^{1,2}$, Magdalena Zvolská ${ }^{1, *}$, Oldřich Jarolím ${ }^{3}$ and Lenka Audrlická Vavrušová ${ }^{1}$ \\ 1 Institute of Environmental and Chemical Engineering, Faculty of Chemical Technology, \\ University of Pardubice, Studentska 573, 53210 Pardubice, Czech Republic; Miloslav.Pouzar@upce.cz (M.P.); \\ Lenka.AudrlickaVavrusova@upce.cz (L.A.V.) \\ 2 Center of Materials and Nanotechnologies (CEMNAT), Faculty of Chemical Technology, \\ University of Pardubice, Nam. Cs. Legii 565, 53002 Pardubice, Czech Republic \\ 3 Department of Waste Management, Czech Environmental Inspectorate, Na Břehu 267, 19000 Praha 9, \\ Czech Republic; Oldrich.Jarolim@cizp.cz \\ * Correspondence: ZvolskaMagdalena@seznam.cz; Tel.: +420-466-037-196
}

Academic Editor: Helena Solo-Gabriele

Received: 14 March 2017; Accepted: 9 May 2017; Published: 12 May 2017

\begin{abstract}
The composition of the surface layer of 13 low-cost jewelry samples with a high Cd content was analyzed using an energy-dispersive X-ray fluorescence spectrometer (ED XRF). The analyzed jewels were obtained in cooperation with the Czech Environmental Inspectorate. The jewels were leached in two types of artificial sweat (acidic and alkaline) for 7 days. Twenty microliters of the resulting solution was subsequently placed on a paper carrier and analyzed by an LIBS (Laser-Induced Breakdown Spectrometry) spectrometer after drying. The Cd content in the jewelry surface layer detected by using ED XRF ranged from $13.4 \%$ to $44.6 \%$ (weight per weight- $w / w$ ). The samples were subsequently leached in artificial alkaline, and the acidic sweat and leachates were analyzed using laser-induced breakdown spectrometry (LIBS). The amount of released $\mathrm{Cd}$ into alkaline sweat ranged from 24.0 to $370 \mu \mathrm{g}$ Cd per week, respectively 3.23-61.7 $\mu \mathrm{g} / \mathrm{cm}^{2} /$ week. The amount of released Cd into acidic sweat ranged from 16.4 to $1517 \mu \mathrm{g}$ Cd per week, respectively $3.53-253 \mu \mathrm{g} / \mathrm{cm}^{2} /$ week. The limit of $\mathrm{Cd}$ for dermal exposure is not unequivocally determined in the countries of the EU (European Union) or in the U.S. Based on the US EPA (United States Environmental Protection Agency) approach used to establish the reference dose (RfD) for $\mathrm{Cd}$ contained in food and information about the bioavailability of $\mathrm{Cd}$ after dermal exposure, we assessed our own value of dermal $\mathrm{RfD}$. The value was compared with the theoretical amount of $\mathrm{Cd}$, which can be absorbed into the organism from jewelry in contact with the skin. The calculation was based on the amount of $\mathrm{Cd}$ that was released into acidic and alkaline sweat. The highest amount of $\mathrm{Cd}$ was released into acidic sweat, which represents $0.1 \%$ of dermal RfD and into alkaline sweat, $0.5 \%$ of dermal RfD. These results indicate that the analyzed jewelry contains $\mathrm{Cd}$ over the limit for composition of jewelry available within the territory of the EU. The determined amount of $\mathrm{Cd}$ in analyzed jewelry does not, however, pose a threat in terms of non-carcinogenic toxic effects.
\end{abstract}

Keywords: health risk; low-cost jewelry; artificial sweat; cadmium; laser-induced breakdown spectrometry

\section{Introduction}

Cadmium is a toxic metal that is easily accumulated in the human body. Even low exposure levels can cause accumulation in human tissues, especially in the kidneys [1]. Chronic cadmium poisoning can inflict renal dysfunction or emphysema, among other afflictions [2]. A number of epidemiological studies have suggested that cadmium is a human carcinogen. According to the EU (European Union) 
regulation (No. 1272/2008) on classification, labeling, and packaging of substances and mixtures, cadmium is classified as carcinogenic (cat. 1B), mutagenic (cat. 2), toxic for reproduction (cat. 2), acutely toxic (cat. 2), and toxic for the aquatic environment.

The European Commission issued a document on the results of a risk evaluation and on risk reduction strategies for cadmium and cadmium oxide (2008/C 149/03) in 2008. The commission concluded that risk management measures were needed for the protection of consumers because of concerns for genotoxicity and carcinogenicity irrespective of the route of exposure, as the substance was considered a non-threshold carcinogen, arising from wearing (imported) jewelry. As of 2011, cadmium has been restricted in jewelry in EU/EEA (European Union/European Economic Area) countries by the REACH (Registration, Evaluation, Authorisation and Restriction of Chemicals) regulation (No. 1907/2008), Annex XVII, entry 23(10). This restriction was implemented by Commission Regulation No. 494/2011 and limits the concentration of cadmium in the metal parts of jewelry and imitation jewelry articles and hair accessories to a maximum of $0.01 \%$ by weight. Jewelry and jewelry-like articles containing cadmium over the limit cannot be placed on the market in EU/EEA countries as of January 2012.

The number of non-compliant jewelry articles on the market is deemed to be extremely high. The Czech Environmental Inspectorate tested, for example, 105 random pieces of jewelry placed on the market in the Czech Republic in 2015. Twenty-three articles contained cadmium levels over the limit. The average cadmium content of those non-compliant articles was $35 \% \mathrm{w} / \mathrm{w}$ (weight per weight). Non-compliant articles were found in 2016 as well, the maximum amount of cadmium found in an article was $91 \% \mathrm{w} / \mathrm{w}$. It can be concluded that cadmium in jewelry is not present as an unwanted contaminant but is rather deliberately used during the production of jewelry articles. Cadmium is used in all probability in the production of such articles due to its favorable properties. It is easy to utilize, resistant to rust, and relatively cheap. Jewelry articles with cadmium are also abundant in other EU/EEA states. The database of the Rapid Exchange of Information System RAPEX (The Rapid Alert System for non-food dangerous products); EU alert system for unsafe consumer products) listed, for example, 157 notifications from member states regarding cadmium jewelry over the 2012-2016 period [3]. Notifications involving cadmium jewelry amounted to $6.5 \%$ of all RAPEX notifications concerning chemical risk in 2016.

Cd content is not only limited in jewelry, but also in other objects of human daily use, such as cosmetics, [4] articles for contact with food [5,6], or children's toys [7]. Cd content is monitored in textile or plastic in EU countries [8], with the Cd limit for both types of articles being $0.01 \mathrm{wt} \%$.

In case of skin contact with objects containing $\mathrm{Cd}$, the possibility of dermal exposure and the emergence of various types of irritation have been discussed. Assays for assessing the dermal toxicity of $\mathrm{Cd}$ have been described in several publications [9-11]. The test of percutaneous absorption of $\mathrm{Cd}$ was also performed on human skin samples [12]. The aim was to determine the absorption of $\mathrm{Cd}$ as a chloride salt from the aqueous solution through human skin into the plasma. Only 0.5 or $0.6 \%$ of the total amount of $\mathrm{Cd}$, which was contained in the aqueous solution, was then absorbed through the skin into the blood plasma. According to the authors, the surface $\mathrm{Cd}$ concentration has an influence on the amount of $\mathrm{Cd}$ diffused into the skin, but $\mathrm{Cd}$ transfer into the plasma is independent from the concentration of $\mathrm{Cd}$ applied to the skin.

To determine the amount of released analyte from a solid sample, it is advisable to perform a leaching test. An artificial human sweat was used as a leaching agent for objects that may come into contact with the skin. A number of model solutions with defined content elements, organic compounds, $\mathrm{pH}$, etc. were discussed. Artificial human sweat has been used to dissolve the chemical components of jewelry, textiles, cosmetics, pharmaceuticals, industrial chemicals, and others [13]. Tests of leaching are often used for determining the amount of released $\mathrm{Ni}$ from objects that are in contact with the skin. $\mathrm{Ni}$ is a significant allergen, which can cause dermatitis and other allergic reactions amongst sensitive individuals. Determination of $\mathrm{Ni}$ in sweat extracts of the analyzed objects has been described in several publications [14-19]. 
Non-destructive methods such as X-ray fluorescence spectrometry (XRF) can be used for analysis of the surface composition of the jewelry [20]. In order to assess the amount of $\mathrm{Cd}$ released from jewelry into human perspiration and for the assessment of dermal exposure, a leaching test with simulated human sweat can be performed. The most commonly used methods for water solution analysis are AAS (Atomic Absorption Spectrometry), ICP OES (Inductively Coupled Plasma Optical Emission Spectrometry), and ICP MS (Inductively Coupled Plasma Mass Spectrometry). Here, we provide a new perspective on the possibility of leachate analysis and the determination of toxic elements in said leachates using Laser-Induced Breakdown Spectrometry (LIBS). Depositing a small solution volume on a solid support can be a suitable alternative method of analysis of leachates and a new option for the assessment of non-compliant subjects. This method could bring several advantages, such as speed of analysis, the minimization of the consumption of the sample, and the possibility of storing the dried samples and adequate detection limits.

\section{Materials and Methods}

\subsection{Samples}

Samples of cheap $\mathrm{Cd}$ containing jewelry were obtained from the Czech Environmental Inspectorate. The subject of our interest was a total of 13 pieces of jewelry ( 3 sets of earrings, 6 pendants, and 1 ring) originating from inspections of three e-shops trading in cheap Chinese goods. Illustrative photos of the analyzed jewelry are shown in Table 1.

Table 1. Surface composition of jewelry from an Energy-Dispersive X-ray Fluorescence Spectrometer (ED-XRF) and parameters of the analyzed samples.

\begin{tabular}{|c|c|c|c|c|c|c|c|c|c|}
\hline & & & ED XR & o, w/u & & & & & \\
\hline Sample & $\mathrm{Cd}$ & $\mathrm{Cu}$ & $\mathrm{Zn}$ & Sn & $\mathrm{Ni}$ & Ag & Area $\left(\mathrm{cm}^{2}\right)$ & Weight (g) & Picture \\
\hline 1B & 44.64 & 35.82 & 5.55 & 0.00 & 13.76 & 0.23 & 6.00 & 5.676 & \\
\hline $2 B$ & 34.52 & 25.78 & 39.71 & 0.00 & 0.00 & 0.00 & 9.00 & 10.24 & \\
\hline $3 B$ & 26.59 & 46.00 & 25.31 & 0.20 & 0.35 & 1.55 & 4.00 & 2.58 & \\
\hline $4 \mathrm{~A}$ & 24.96 & 64.73 & 8.20 & 0.21 & 0.47 & 1.42 & 3.00 & 4.21 & \\
\hline $6 \mathrm{~A}$ & 29.13 & 57.07 & 7.18 & 0.00 & 0.00 & 6.63 & 1.00 & 3.59 & \\
\hline $7 \mathrm{~A}$ & 13.69 & 65.01 & 20.00 & 0.00 & 0.93 & 0.37 & 6.25 & 4.07 & \\
\hline $9 \mathrm{~A}$ & 29.11 & 38.06 & 32.00 & 0.00 & 0.58 & 0.25 & 9.00 & 4.63 & \\
\hline $5 \mathrm{~A}$ & 25.73 & 64.30 & 9.20 & 0.00 & 0.54 & 0.24 & 12.50 & 4.80 & \\
\hline
\end{tabular}


Table 1. Cont.

\begin{tabular}{|c|c|c|c|c|c|c|c|c|c|}
\hline & & & ED XR & $o, w / w$ & & & & & \\
\hline Sample & Cd & $\mathrm{Cu}$ & $\mathrm{Zn}$ & Sn & $\mathrm{Ni}$ & $\mathrm{Ag}$ & Area $\left(\mathrm{cm}^{2}\right)$ & Weight (g) & Picture \\
\hline $10 \mathrm{~A}$ & 19.50 & 52.49 & 26.63 & 0.39 & 0.34 & 0.65 & 4.00 & 2.88 & \\
\hline Ring & 13.40 & 85.41 & 0.54 & 0.15 & 0.49 & 0.00 & 3.00 & 7.09 & \\
\hline
\end{tabular}

\subsection{Analysis of Surface Composition}

The surface composition of the samples was analyzed using an Elva X energy-dispersive X-ray fluorescence spectrometer (Elvatech Ltd., Kiev, Ukraine) equipped with a Pd X-ray tube and a thermoelectrically cooled Si-pin detector, PF 550 (MOXTEC, Orem, UT, USA). The power supply of the X-ray tube was operated at $40 \mathrm{kV}$, and the current was set via the auto-optimization procedure taking into account the optimal loading of the detector in a range of 6000-6500 counts per second (cps). The spectra were integrated for $90 \mathrm{~s}$. Each sample was analyzed at five measuring points evenly spaced on that part of the sample that was supposed to be in contact with the skin. Parts of the sample that usually do not come in direct long-term contact with the skin, such as the solder holding the stone, were omitted from the analysis. Concentrations of elements detected in the samples were calculated by the standard-less module based on the fundamental parameters method.

\subsection{Leaching the Samples in an Artificial Sweat}

The leaching of jewelry samples was performed with two types of artificial sweat-acidic and alkaline [21]. Acidic sweat was prepared dissolving $0.5 \mathrm{~g}$ of L-histidine mono-chloride monohydrate $\left(\mathrm{C}_{6} \mathrm{H}_{9} \mathrm{O}_{2} \mathrm{~N}_{3} \cdot \mathrm{HCl} \cdot \mathrm{H}_{2} \mathrm{O}\right), 5 \mathrm{~g}$ of $\mathrm{NaCl}$, and $2.2 \mathrm{~g}$ of $\mathrm{NaH}_{2} \mathrm{PO}_{4} \cdot 2 \mathrm{H}_{2} \mathrm{O}$ in $1 \mathrm{~L}$ of demineralized water. The $\mathrm{pH}$ value was adjusted by $0.1 \mathrm{moL} \cdot \mathrm{L}^{-1} \mathrm{NaOH}$ to 5.5. To prepare $1 \mathrm{~L}$ of alkaline sweat, $0.5 \mathrm{~g}$ of $\mathrm{C}_{6} \mathrm{H}_{9} \mathrm{O}_{2} \mathrm{~N}_{3} \cdot \mathrm{HCl} \cdot \mathrm{H}_{2} \mathrm{O}, 5 \mathrm{~g}$ of $\mathrm{NaCl}$ and $5 \mathrm{~g}$ of $\mathrm{Na}_{2} \mathrm{HPO}_{4} \cdot 12 \mathrm{H}_{2} \mathrm{O}$ was diluted in demineralized water. A solution of $\mathrm{NaOH}$ of a concentration of $0.1 \mathrm{moL} \cdot \mathrm{L}^{-1}$ was added for a $\mathrm{pH}$ adjustment to 8 . The volume of artificial sweat for the leaching of the particular jewelry piece was chosen based on the sample surface area, so that $1 \mathrm{~mL}$ of the reagent was used for each $1 \mathrm{~cm}^{2}$ of the surface. The sample parts, which were not supposed to come into direct contact with the skin (e.g., stones), were not included into the calculated surface. These parts were covered by resistant adhesive tape during leaching to prevent the release of $\mathrm{Cd}$. The leaching procedure lasted 7 days and was performed at $37^{\circ} \mathrm{C}$. The pieces of jewelry were then removed from the leachate, and $20 \mu \mathrm{L}$ of the solution was spotted onto a circular piece of paper with a diameter of $17 \mathrm{~mm}$ and dried under an infrared lamp.

Leachate samples deposited on the paper carrier were analyzed using the commercially available compact LIBS spectrometer (LEA S500, Solar TII Ltd., Minsk, Belarus). The system consists of a dual pulse Q-switched Nd:YAG (Neodymium-doped Yttrium Aluminum Garnet) laser operating at $1064 \mathrm{~nm}$. A nanosecond laser emitting two collinear pulses of $12 \mathrm{~ns}$ was operated at double-pulse mode with an inter-pulse delay of $7 \mu \mathrm{s}$. A laser beam with an energy of $110 \mathrm{~mJ}$ was focused on the sample surface, where the analytical point with a diameter of $200 \mu \mathrm{m}$ was ablated. Each sample was analyzed at nine independent analytical points, while every point was ablated by one laser shot. Radiation emitted by arising plasma was led through the entrance slit of $25 \mu \mathrm{m}$ into a Czerny-Turner monochromator and the spectral window in a range from 205 to $235 \mathrm{~nm}$ was recorded by a back-thinned and front-illuminated CCD (Charge-Coupled Device) camera (2048 $\times 14$ pixels). Quantitative analysis of Cd was carried out on an analytical line of $214.441 \mathrm{~nm}$. Separate calibration curves were constructed for acidic and alkaline sweat samples in a range from 0 to $40 \mathrm{mg} \cdot \mathrm{L}^{-1}$. Solutions of artificial sweat, spiked with $\mathrm{Cd}$, 
were used as calibration standards. The precision and accuracy of the LIBS methods was validated comparing LIBS and ICP OES for a set of 5 samples of each sweat type. The mean concentration values measured by both methods were equal, although the LIBS results suffered from a higher standard deviation. The sample volume needed for the analysis was substantially lower, by contrast, in the case of LIBS, and this method also offered the possibility of the long-term storage of liquid samples deposited on the solid carrier.

\section{Results and Discussion}

\subsection{Surface Analysis}

The analyzed jewelry samples revealed a truly variable surface composition. As can be seen in Table 1, the surface layer of all the samples contained Cd (13.4-44.6\%), Zn (0.5-39.7\%), and Cu (25.8-85.4\%). A measurable content of Ag was contained in 11 out of the 12 samples (0.2-1.6\%); Sn was detected in 4 samples $(0.2-04 \%)$, and $\mathrm{Ni}$ was detected in 8 samples $(0.3-13.8 \%)$. The $\mathrm{Cd}$ concentrations detected in the jewelry samples using ED XRF significantly exceeded the appropriate limits valid in the EU $(0.01 \%)$, the USA $(0.03 \%)$, and Canada $(0.013 \%)$.

\subsection{Leaching in Artificial Sweat}

After measuring calibration standards, the limit of detection (LOD) for both acid and alkaline artificial sweat solutions was determined. The LOD was determined according to definition $3 \sigma / s$, where $\sigma$ is the standard deviation of intensity calculated from 36 repeated measurements of the lowest calibration standard (blank) performed under optimal conditions, and $s$ is the slope of the calibration curve. The calculated LOD has a value of $0.08 \mathrm{mg} \cdot \mathrm{L}^{-1}$ and $0.06 \mathrm{mg} \cdot \mathrm{L}^{-1}$ for acidic and alkaline artificial sweat, respectively. The relative standard deviation (RSD; \%) calculated for measuring data of jewelry leachates was in a range from $4.79 \%$ to $22.6 \%$.

One piece of each pair of earrings $(1 \mathrm{~B}, 2 \mathrm{~B}$, and $3 \mathrm{~B})$ was leached in acidic and one piece in alkaline artificial sweat. Data presented in Table 2 reveal that the total amount of cadmium, which was released into the alkaline sweat, constitutes in all cases about $20 \%$ of the amount released into the acidic sweat. Apart from the earrings, four pieces of pendants (4A, 6A, 7A, and 9A) were leached in alkaline sweat and two pieces of pendants (5A and 10A) together with one piece of ring in acidic sweat. The total amounts of $\mathrm{Cd}$ released into the particular types of artificial sweat are not clearly correlated with the $\mathrm{Cd}$ content in the sample surface layer. The correlation coefficients calculated for $\mathrm{Cd}$ content in jewelry and in alkaline $(r=0.786, p=0.04)$ or in acidic sweat $(r=0.830, p=0.04)$ were quite high, but these results were strongly biased by the influential point of $1 \mathrm{~B}$. After exclusion of the influential 1B point, the correlation coefficients significantly decreased (alkaline sweat $r=0.614, p=0.19$; acidic sweat $r=0.607, p=0.28)$. The same relations were observed when the correlation coefficients were calculated for $\mathrm{Cd}$ content measured by ED XRF and for $\mathrm{Cd}$ released from one square centimeter of sample over one week (\% Cd w/w vs. $\mu \mathrm{g} \mathrm{Cd} / \mathrm{cm}^{2} /$ week). The correlation coefficients for alkaline $(r=0.763$, $p=0.05)$ and acidic $(r=0.741, p=0.09)$ sweat were also quite high and similar, but these results were also biased by the influential point of 1B. In this case, the sharp decline in the correlation coefficient was also observed after exclusion of the influential 1B point (alkaline sweat $r=0.312, p=0.55$; acidic sweat $r=0.56, p=0.33$ ). It is apparent that the available set of samples is too small in number to be able to clearly describe the relationship between the surface composition of the sample and the amount of leached cadmium. Streicher porte et al. in their work from 2008 analyzed 21 samples of low cost jewelry containing $1.4-43.9 \%$ of $\mathrm{Cd}$ on the surface layer. Migration of the toxic metals was tested after sample submersion in $0.07 \mathrm{M} \mathrm{HCl}$ (Hydrochloric acid-simulation of gastric acid) for 7 days at $30{ }^{\circ} \mathrm{C}$ [20]. The observed correlation between the released $\mathrm{Cd}$ in $\mu \mathrm{g} / \mathrm{cm}^{2} /$ week was low $(r=0.49)$, which is in agreement with our results, if we evaluate the correlation after exclusion of the influential points.

The obtained sample set contained 3 pairs of earrings. One earring out of the pair was leached in acidic and the other in alkaline artificial sweat. When comparing the results from leachate extracts for 
pairs of earrings, alkaline artificial sweat provided higher results for dissolved $\mathrm{Cd}$. This is surprising because it is generally assumed that metals are better dissolved in an acidic environment.

Table 2. The total amount of cadmium that was released into the artificial sweat, and calculated values for MADD and RCR.

\begin{tabular}{cccccc}
\hline Sample & $\begin{array}{c}\text { Sweat } \\
\text { Type }\end{array}$ & $\begin{array}{c}\text { TRA Cd } \\
(\mu \mathrm{g} / \text { Week })\end{array}$ & $\begin{array}{c}\text { TRA Cd } \\
\left(\mu \mathrm{g} / \mathbf{c m}^{2} / \text { Week }\right)\end{array}$ & $\begin{array}{c}\text { MADD } \\
(\mu \mathrm{g} / \mathbf{k g} / \mathrm{Day})\end{array}$ & RCR (\%) \\
\hline 1B & Alkaline & 370.4 & 61.73 & $4.54 \times 10^{-3}$ & $1.13 \times 10^{-1}$ \\
2B & Alkaline & 72.70 & 8.078 & $8.90 \times 10^{-3}$ & $2.23 \times 10^{-2}$ \\
3B & Alkaline & 49.01 & 12.25 & $6.00 \times 10^{-4}$ & $1.50 \times 10^{-2}$ \\
4A & Alkaline & 29.37 & 9.789 & $3.60 \times 10^{-4}$ & $8.99 \times 10^{-3}$ \\
6A & Alkaline & 24.55 & 24.55 & $3.01 \times 10^{-4}$ & $7.52 \times 10^{-3}$ \\
7A & Alkaline & 24.00 & 3.840 & $2.94 \times 10^{-4}$ & $7.35 \times 10^{-3}$ \\
9A & Alkaline & 29.09 & 3.232 & $3.56 \times 10^{-4}$ & $8.90 \times 10^{-3}$ \\
1B & Acidic & 1517 & 252.9 & $1.86 \times 10^{-2}$ & $4.64 \times 10^{-1}$ \\
2B & Acidic & 340.5 & 37.83 & $4.17 \times 10^{-3}$ & $1.04 \times 10^{-1}$ \\
3B & Acidic & 222.3 & 55.585 & $2.72 \times 10^{-3}$ & $6.81 \times 10^{-2}$ \\
5A & Acidic & 44.14 & 3.532 & $5.41 \times 10^{-4}$ & $1.35 \times 10^{-2}$ \\
10A & Acidic & 16.36 & 4.089 & $2.00 \times 10^{-4}$ & $5.01 \times 10^{-3}$ \\
Ring & Acidic & 154.6 & 51.53 & $1.89 \times 10^{-3}$ & $4.73 \times 10^{-2}$ \\
\hline
\end{tabular}

TRA Cd-total released amount of Cd per 1 week; TRA Cd *-total released amount of Cd per 1 week from $1 \mathrm{~cm}^{2}$ of jewelry; MADD—maximum absorbable daily dose; RCR—risk characterization ratio.

\subsection{Systemic Non-Carcinogenic Health Risk of Released Cd}

A reference dose (RfD) is the regulatory limit established by the United States Environmental Protection Agency (US EPA) representing the maximum oral dose of a toxic substance, below which no adverse non-carcinogenic health effects should result from a lifetime of exposure. According to the Integrated Risk Information System [22], the calculation of RfD for chronic oral exposure was based on the assumption of increased proteinuria occurring when the $\mathrm{Cd}$ content in the renal cortex exceeds the value of $200 \mu \mathrm{g} \mathrm{Cd} / \mathrm{g}$ wet tissue. Cd daily intake of $0.352 \mathrm{mg}$ (or $0.005 \mathrm{mg} / \mathrm{kg} / \mathrm{day}$ for $70-\mathrm{kg}$ adult), which is necessary in order for the concentration of this element in the renal cortex to reach the critical value, was estimated based on the work of Friberg et al. [23]. This work assumed a Cd biological half-life $\left(\mathrm{t}_{1 / 2}\right)$ of 19 years, an exposure duration of 50 years, and an absorption of $4.5 \%$ of $\mathrm{Cd}$ contained in the food. US EPA postulated only $2.5 \%$ absorption of $\mathrm{Cd}$ from the food and consequently established the NOAEL (No-Observed-Adverse-Effect Level) value of $0.01 \mathrm{mg}$ of $\mathrm{Cd} / \mathrm{kg} /$ day. RfD of $0.001 \mathrm{Cd} / \mathrm{kg} /$ day was then obtained dividing NOAEL by the uncertainty factor (UF) of 10. The US EPA document shared at the IRIS (Integrated Risk Information System) database unfortunately does not provide any further information regarding the used toxicokinetic model. When the one-compartment standard first-order elimination model with bolus administration described by Amzal et al. [24] was used, the same value of NOAEL $(0.01 \mathrm{mg} \mathrm{Cd} / \mathrm{kg} /$ day) was obtained for the subsequent set of parameters: a Cd gastrointestinal absorption index equal to $2.5 \%$; a fraction of absorbed $\mathrm{Cd}$ transported to the kidney equal to $33 \%$; a ratio of $\mathrm{Cd}$ content in the entire kidney and renal cortex of 1.25; a kidney weight of equal to $300 \mathrm{~g}$; and a Cd biological half-life $\mathrm{t}_{1 / 2}$ of 18.3 years.

The EPA did not establish a limit of a similar meaning as the RfD for dermal exposure. To be able to assess the health risk of $\mathrm{Cd}$ released from low-cost jewelry, we performed our own approximation of dermal RfD based on the same toxicokinetic model. The parameters mentioned above were used except for the absorption index, which was set to $0.6 \%$. The calculated value of NOAEL for dermal exposure was $0.042 \mathrm{mg} / \mathrm{kg} /$ day. The resulting dermal RfD in this case was also obtained dividing NOAEL by the uncertainty factor UF $=10$ with a value of $0.004 \mathrm{mg} / \mathrm{kg} /$ day. The dermal RfD estimated in such a way represents a kind of worst-case scenario, in as much as the $\mathrm{Cd}$ absorption into the plasma could be lower than the absorption into the renal cortex with published data for absorption into the plasma varying between $0.1 \%$ and $0.6 \%$ [11]. 
The total amounts of $\mathrm{Cd}$ in $\mu \mathrm{g}$ released from a particular piece of jewelry (TRA-Total Released Amount) into acidic or alkaline artificial sweats over one week of leaching are summarized in Table 1. The maximum absorbable daily dose (MADD) of Cd from a particular piece of jewelry was calculated based on the assumed Cd bioavailability of $0.6 \%$ and an average human body weight of $70 \mathrm{~kg}$ according to the following equation: $\mathrm{MADD}=0.006 \times \mathrm{TRA} /(70 \times 7)$. A factor of 7 in the denominator was used to convert the amount of $\mathrm{Cd}$ released over one week of leaching to the daily exposure. The risk characterization ratio (RCR) was then calculated as the hundredfold ratio of MADD and RfD. This factor serves as an estimate as to what percentage of the safe daily dose can be covered by $\mathrm{Cd}$ released from the jewelry. The amount of $\mathrm{Cd}$ leached into alkaline artificial sweat typically represents about $0.01-0.02 \%$ of the safe daily dose, while the maximal RCR for Sample $1 \mathrm{~B}$ was $0.1 \%$. In the case of acidic artificial sweat, RCR values are higher and more variable (ranging from $0.05 \%$ to $0.46 \%$ ). Although the process of health risk estimation used is extremely simplified, it can be concluded that the evaluated set of $\mathrm{Cd}$ containing jewelry do not pose any serious health risk in terms of systemic non-carcinogenic effects.

\section{Conclusions}

A composition of a surface layer of 13 low cost jewelry samples with a high content of $C d$ was analyzed by ED XRF. These samples were subsequently leached in artificial acidic and alkaline sweat, and the resulting digests were applied onto solid carriers and analyzed by LIBS. The content of Cd in the jewelry surface layer ranged from $13.40 \%$ to $44.64 \%(\mathrm{w} / \mathrm{w})$ with the measured values significantly exceeding permissible limits in the EU or U.S. The results of the analysis suggest that this jewelry should not be available in the countries of the EU. The analysis of the leachates indicates that acidic artificial sweat released an amount of $\mathrm{Cd}$ roughly 5-fold higher than that of artificial alkaline sweat. The relationship between the surface composition of the samples and the amount of $\mathrm{Cd}$ released into artificial sweat was not clearly demonstrated. The low bioavailability of $\mathrm{Cd}$ for dermal exposure, along with the small amounts of $\mathrm{Cd}$ released from the surface layer of the jewelry, leads to the conclusion that even the long-term use of these jewels does not constitute major health risks in terms of the biological and toxic effect of $\mathrm{Cd}$. The maximum amount of released $\mathrm{Cd}$ from the analyzed jewelry makes up about $0.5 \%$ of a safe dose.

Acknowledgments: We thank Pavel Čičmanec (University of Pardubice, Department of Physical Chemistry) for valuable advice.

Author Contributions: Miloslav Pouzar analyzed samples by ED XRF and designed the calculation of Health Risk Assessment. Magdalena Zvolská prepared samples and leachates for analysis and analyzed samples by LIBS. Oldřich Jarolím provided samples of jewelry and designed the calculation of Health Risk Assessment. Lenka Audrlická Vavrušová designed the calculation of Health Risk Assessment. Miloslav Pouzar and Magdalena Zvolská wrote the paper and Oldřich Jarolím revised the document.

Conflicts of Interest: The authors declare no conflict of interest.

\section{References}

1. Satarug, S.; Baker, J.R.; Reilly, P.E.; Moore, M.R.; Williams, J.D. Cadmium levels in the lung, liver, kidney cortex, and urine samples from Australians without occupational exposure to metals. Arch. Environ. Health Int. J. 2002, 57, 69-77. [CrossRef] [PubMed]

2. Friberg, L.; Elinder, C.G.; Kjellstrom, T. International Programme on Chemical Safety; Environmental Health Criteria-Cadmium: Geneve, Switzerland, 1992.

3. RAPEX. Rapid Alert System for dangerous non-food products. In European Commission's Directorate General for Justice and Consumers; European Commission: Brussel, Belgium, 2017.

4. Regulation No. 1223/2009, Regulation (EC) No. 1223/2009 of the European Parliament and of the Council of 30 November 2009 on Cosmetic Products, in EUR-Lex, EUR-Lex Access to European Union Law. Available online: http://eur-lex.europa.eu/legal-content/EN/ALL/?uri=CELEX\%3A32009R1223 (accessed on 10 March 2017). 
5. International Organization for Standardization. International Standard ISO 6486-2, Ceramic Ware, Glass-Ceramic Ware and Glass Dinnerware in Contact with Food_Release of Lead and Cadmium-Part 2: Permissible Limits; International Organization for Standardization: Geneva, Switzerland, 1999.

6. International Organization for Standardization. International Standard ISO 7086-2, Glass Hollowware in Contact with Food-Release of Lead and Cadmium_Part 2: Permissible Limits; International Organization for Standardization: Geneva, Switzerland, 2000.

7. Guney, M.; Zagury, G.J. Heavy metals in toys and low-cost jewelry: Critical review of U.S. and Canadian legislations and recommendations for testing. Environ. Sci. Technol. 2012, 46, 4265-4274. [CrossRef] [PubMed]

8. Commission Regulation (EU). No. 835/2012, in Official Journal of the European Union. Available online: http:/ / eur-lex.europa.eu/legal-content/EN/TXT/?uri=celex\%3A32012R0835 (accessed on 10 March 2017).

9. Fasanya-Odewumi, C.; Latinwo, L.M.; Ikediobi, C.O.; Gilliard, L.; Sponholtz, G.; Nwoga, J.; Stino, F.; Hamilton, N.; Erdos, G.W. The genotoxicity and cytotoxicity of dermally-administered cadmium: Effects of dermal cadmium administration. Int. J. Mol. Med. 1998, 1, 1001-1006. [CrossRef] [PubMed]

10. Lansdown, A.B.G.; Sampson, B. Dermal toxicity and percutaneous absorption of cadmium in rats and mice. Lab. Anim. Sci. 1996, 46, 549-554. [PubMed]

11. Strandesen, M.; Poulsen, P.B. Survey of Chemical Substances in Consumer Products, No. 94-Survey and Health Assessment of Chemical Substances in Jewelleries; Danish Ministry of the Evironment, Environmental Protection Agency: Copenhagen, Denmark, 2008.

12. Wester, R.C.; Maibach, H.I.; Sedik, L.; Melendres, J.; DiZio, S.; Wade, M. In vitro percutaneous absorption of cadmium from water and soil into human skin. Fundam. Appl. Toxic. 1992, 19, 1-5. [CrossRef]

13. Stefaniak, A.B.; Harvey, C.J. Dissolution of materials in artificial skin surface film liquids. Toxicol. In Vitro 2006, 20, 1265-1283. [CrossRef] [PubMed]

14. Milosev, I.; Kosec, T. Metal ion release and surface composition of the Cu-18Ni-20Zn nickel-silver during 30 days immersion in artificial sweat. Appl. Surf. Sci. 2007, 254, 644-652. [CrossRef]

15. Pouzar, M.; Schmidt, M.; Krejčová, A.; Černohorský, T. Nickel release from piercing jewellery. SRX Chem. 2010, 2010, 769070. [CrossRef]

16. Rezic, I.; Zeiner, M.; Steffan, I. Determination of allergy-causing metals from coins. Monatshefte Chem. 2009, 140, 147-151. [CrossRef]

17. Rezic, I.; Curkovic, L.; Ujevic, M. Metal ion release from electric guitar strings in artificial sweat. Corros. Sci. 2009, 51, 1985-1989. [CrossRef]

18. Midander, K.; Pan, J.; Wallinder, I.O.; Heim, K.; Leygraf, C. Nickel release from nickel particles in artificial sweat. Contact Dermat. 2007, 56, 325-330. [CrossRef] [PubMed]

19. Hamann, D.; Thyssen, J.P.; Hamann, C.R.; Hamann, C.; Menné, T.; Johansen, J.D.; Spiewak, R.; Maibach, H.; Lundgren, L.; Lidén, C. Jewellery: Alloy composition and release of nickel, cobalt and lead assessed with the EU synthetic sweat method. Contact Dermat. 2015, 73, 231-238. [CrossRef] [PubMed]

20. Streicher-Porte, M.; Buckenmayer, A.; Pfenninger, S. What goes around comes around? High levels of cadmium in low cost jewelry. In Proceedings of the IEEE International Symposium on Electronics and the Environment (ISEE 2008), San Francisco, CA, USA, 19-22 May 2008; IEEE: San Francisco, CA, USA, 2008.; pp. 1-5.

21. Randin, J.P. Corrosion behavior of nickel-containing alloys in artificial sweat. J. Biomed. Mater. Res. Part A 1988, 22, 649-666. [CrossRef] [PubMed]

22. Integrated Risk Information System (IRIS): U.S. Environmental Protection Agency; National Center for Environmental Assessment. Chemical Assessment Summary; National Academics Press: Washington, DC, USA, 2017.

23. Friberg, L.; Piscator, M.; Nordberg, G.F.; Kjellström, T. Cadmium in the Environment; CRC Press: Ithaca, NY, USA, 1974.

24. Amzal, B.; Julin, B.; Vahter, M.; Wolk, A.; Johanson, G.; Akesson, A. Population toxicokinetic modeling of cadmium for health risk assessment. Environ. Health Perspect. 2009, 117, 1293-1301. [CrossRef] [PubMed]

(C) 2017 by the authors. Licensee MDPI, Basel, Switzerland. This article is an open access article distributed under the terms and conditions of the Creative Commons Attribution (CC BY) license (http:/ / creativecommons.org/licenses/by/4.0/). 